An International Multidisciplinary Double-Blind Peer-reviewed Research Journal

\title{
Utilizing the World Café Method to Inboost Students' Motivation and Learning Outcomes
}

\author{
Ahmad Al Yakin ${ }^{1}$ Abdul Wafi ${ }^{2}$ Vinni Harianti ${ }^{3}$ \\ ${ }^{1}$ Civics Study Program, Faculty of Teacher Training and Education, \\ University of Al Asyariah Mandar \\ ahmadalyakin76@gmail.com
}

\begin{abstract}
This research is an experimental study involving a group of class VIIa students as an experimental class that aims to determine the effectiveness of the word café method on the motivation and learning outcomes of Civics Education subject at SMP Negeri 1 Mehalaan. The study used an experimental research design-the data collection technique from pretest-posttest and questionnaire. The results showed that the average pre-test score was $40.00<\mathrm{KKM}$ (Minimum Mastery Criteria), or $85 \%$ classical completeness was not achieved based on descriptive analysis in the experimental class. While the average post-test score of 78.00> KKM or achieving classical completeness $85 \%$, while for the results of the descriptive analysis in the control class obtained an average value of pre-test of $45.50<\mathrm{KKM}$ or not achieving classical completeness $85 \%$ and the value of post-test average of $59.00<\mathrm{KKM}$. Based on the analysis of non-tests obtained, students' activity in the experimental class fulfilled the activeness criteria, which reached $76.25 \%$; that means the use of the World Café method is more successful in enhancing the student's motivation and learning outcomes civics education subject.
\end{abstract}

Keywords: Effectiveness, World Café Method, Motivation and Learning Outcomes.

\section{INTRODUCTION}

Education is one way to improve personality, civilization, and progress of nation after nation that will come. National education is based on the culture of the Indonesian country based on Pancasila and the 1945 Constitution, which mandates efforts to educate the nation's life. (Isaac, 2017: 75) According to Hanushek, (2007), Thomas, V., (1999); Holsinger, (2009), education quality is essential for achieving the objective of education and needs to be guaranteed; nevertheless, it is often not very adequate and will certainly always have space for development. In this respect, a lot of studies have focused on this subject. Since education is crucial for human progress and is considered a human right, excellent education is one of the worldwide aims of many other development objectives. These objectives emphasize equal access to schools and excellent education, and the success of all students with varied backgrounds in schooling. Extensive study has been done to explore and identify diverse patterns and underlying reasons for the educational disparity to provide references and proposals for further policy development and implementation.

A recent study on Civic Education shows a need to improve on current Civic Education curricula in several areas. These materials are currently aimed at a conservative version of civic education rather than citizenship education, with more progressive objectives, long recognized as a problem of education, imparting moral principles that are considered a source of social goods. The teaching of good and poor behavior and the transformation of bad behavior into good ones are a matter of education. Every moral discipline specifies the action that is regarded as righteous by a criterion of its principles, even though the presence of ethical individuals is prevalent in practically all civilizations. Becerikli, S., \& Y1ldırım, S. G. (2018).

The need for active and effective citizenship in dealing with social or even global problems is evident. For this reason, initiatives to promote knowledge, skills, and direct values are expanding in developed countriesespecially to urge young people to become active, influential, and participating people Wood, J. (2010). Education systems have also given rise to ideal on what a good citizen should be. The notion of a good citizen differs between communities, governments, and systems of administration. In certain societies, there is a close association between being a decent person and honoring national interests and the symbols such as flags and anthems Kadio glu, (2008). But being a good citizen is synonymous with following the king's commands in other societies. In brief, the fundamental objective of citizenship education can be described as excellent citizens' training. Citizenship education is about individuals' abilities to decide their life and accept responsibility for the society they live in. Citizenship education also aims at supporting good citizens and trained people who are aware of political issues in their own country and the globe, who respect others, embrace equality for everyone, prioritize peace and combat all types of discrimination; UNESCO, (2019).

Citizenship education contributes to the understanding of state institutions and principles by individuals, to the learning of decisions and the development of a sense of individual and societal responsibility. Citizenship education strengthens individuals' skills and values in terms of their rights and obligations. To progress, societies need citizens who are active, effective, knowledgeable and eager to accept responsibility and to engage in political processes for themselves and their communities. Citizenship education should be seen as a learner process that not only receives but also produces and sustainers knowledge for life. The success of citizenship education depends on the ability of individuals to acquire awareness, skills, beliefs and democratic habits, both 
An International Multidisciplinary Double-Blind Peer-reviewed Research Journal

in their adulthood and their schooling. For this reason, adult education is becoming highly relevant to a functioning democratic society. Politicians and educators agree that lifetime learning should continue and that lifelong learning is crucial to everyone.

The longstanding view that places learning as a process of transferring information or transfer of knowledge from teachers to students is getting more and more criticism. The placement of teachers as the only source of information places students not as dynamic individuals but rather as passive objects so that their individual potential cannot develop optimally. (Anurrahman 2014: 9)

Based on the results of observations, the learning process at SMP Negeri 1 Mehalaan currently tends to be still teacher-centered by telling stories or lectures. Students are less actively involved in the learning process because the teacher's role is very dominant as the only source of learning. It causes the level of student understanding of the subject matter to be low, and the expected learning outcomes are not achieved optimally. And the students' learning motivation in the class has not been maximized. It is indicated by the average value of the class being obtained by students on the results of daily tests prior subject of 60 proves that the student has not reached Minimum Mastery Criteria (KKM) as determined by teachers of subjects that is 70 (Results of observations Researcher On Date 7-8 June 2020).

\section{RESEARCH METHOD}

The research was carried out at SMP Negeri 1 Mehalaan, Mamasa Regency on January 2020, and is a type of Quasi Experimental Research carried out by choosing two classes, namely VII A as the Experiment class and given treatment using the world café method, and VII B as the Control class without being given any treatment. The research design used the Pretest-Posttest Control Group Research Design. The research design is as follows: Table 1. Research Design Pretest-Posttest Control Group Design

\begin{tabular}{|l|l|l|l|}
\hline Group & Pre-test & Treatment & Post-test \\
\hline Experiment & $\mathrm{O} 1$ & $\mathrm{X}$ & $\mathrm{O} 2$ \\
\hline Control & $\mathrm{O} 3$ & & $\mathrm{O} 4$ \\
\hline
\end{tabular}

Source: Sugiyono, $(2013: 112)$

According to Drew \& Guillemin, (2014), there are three steps of the World Café technique. Step 1 "meaning through participant involvement" refers to the design of World Café data gathering events. In line with the first principle - Setting the context - the researcher held two World Café events, each with 20 attendees. The participants pretend they are in the local café built a coffee-like environment for small groups of up to five individuals, covered with paper tablecloths for notes, index cards, sticky notes, and a selection of colored pencils using the second concept - to create an inviting stage (Steier et al., 2015). Tea and coffee and buffet lunch were served with networking possibilities and talking with their group; they were divided into four groups. (Ritch \& Brennan, 2011).

Then, encouraging everyone's input and connecting varied viewpoints - were employed to make it possible to communicate helpful knowledge. Every World Café event was organized following the fifth and sixth principles - Listen and identify patterns and share group discoveries. Each cluster sat around a table and was asked a question by a nominated host. Participants freely selected whether, how, and when to participate. Three rounds of the talk were held at a World Café. Each round dealt with one of our research issues. Between each round there were breaks. The purpose of the World Café is to apply various viewpoints on a problem.

In Step 2 "meaning-making through researchers' involvement,". In this stage, the participants keep conversation relaxed, building on other insight, listening and commenting each other. Each participant in group must be involved, listening together for patterns and insight that emerged the discussion looked for reoccurring ideas and topics before signaled to move to another table

In Step 3 "Making through Reconceptualization" (Drew \& Guillemin, 2014), they commented on the information and ideas employed and on how they should be perceived. At the 15 minutes the participants were asked to mark the information discuss shared to each participants

\section{RESULTS AND DISCUSSION}

The research was carried out within a period of two weeks, starting January 27 to 8 February 2020. The course of the research is in experiment group by using the World Café method and control group without using World Café method. The results obtained in this research were quantitative data and qualitative data. Quantitative data were obtained from the results of the pre- test and post-test. Quantitative data were analyzed by using the help of the SPSS program computational system version 21. The data were obtained from the results of student activities during research. Both data were processed and analyzed in order to get the conclusions of the research results 
An International Multidisciplinary Double-Blind Peer-reviewed Research Journal

\section{Student Learning Outcomes of SMP Negeri 1 Mehalaan}

The descriptive statistics analysis of pretest and post-test were based on the descriptive analysis by using computerized system of SPSS version 21, using descriptive statistics frequencies. The followings are the results of the test values of Civics subject of the student's class VII Negri 1 Mehalaan subdistrict Mehalaan Mamasa. Table 1. Descriptive of Post-Test Learning Outcomes for Experimental Class Students

\begin{tabular}{|l|l|l|l|l|}
\hline KKM & Score & Category & Frequency & Percentage (\%) \\
\hline \multirow{3}{*}{70} & $0-69$ & Not Complete & 4 & 20 \\
\cline { 2 - 5 } & $70-100$ & Complete & 16 & 80 \\
\cline { 2 - 5 } & amount & 20 & 100 \\
\hline
\end{tabular}

Based on Table 1, it can be seen that number of learners for the experiment group in post-test, the learners who were successfully passed the test were 16 in the percentage of $80 \%$; the learners who did not pass the test were 4 students in the percentage of $20 \%$. The followings are the test scores for the control class civic education learning outcomes based on the descriptive analysis using a computerized system, the SPSS version 21 program uses descriptive statistics frequencies.

Table 2. Descriptive Statistics of Pre- Test and Post- Test Control Classes

\section{Statistics}

\begin{tabular}{|l|l|l|}
\hline & $\begin{array}{l}\text { Control class } \\
\text { pre test } \text { scores }\end{array}$ & $\begin{array}{l}\text { control group } \\
\text { post test } \text { scores }\end{array}$ \\
\hline valid & 20 & 20 \\
Mean miss & 0 & 0 \\
Std. Error of Mean & 45.50 & 59.00 \\
median & 4.134 & 3.317 \\
Mode & 50.00 & 60.00 \\
Std. Deviation & 30 a & 70 \\
Variance & 18,489 & 14,832 \\
Range & 341,842 & 220,000 \\
Minimum & 70 & 50 \\
Maximum & 0 & 30 \\
Sum & 70 & 80 \\
\hline
\end{tabular}

Source: SPSS analysis version 21

Based on table 2, it is explained that the pre-test value of the Civics Subject of the control group students is a maximum of 70 for the low one achieved is 0 . The score range is 70 , the average is 45.50 and the resulting midpoint is 50.00 and the score that often appears 30 . So, the standard deviation resulting from the data on the value of Civics learning outcomes achieved by the control class students is 18.489. Meanwhile, for the post-test value of control class is 80 in maximum and 30 in minimum; so, the range of scores is 50, average 59.00, 60.00 midpoint produced results that mostly appears that 70 deviation from the value of post-test were achieved by students are 14,832 then the variance of the data is 220,000 .

able 3: Normality of Pretest Value of Experiment Class and Control Class

tics

\begin{tabular}{|l|l|l|}
\hline & experimental class pre test scores & control class pre test scores \\
\hline Chi-Square & $9,700^{\mathrm{a}}$ & $3,800^{\mathrm{b}}$ \\
df & 8 & 6 \\
asymp. Sig. & .287 & .704 \\
\hline
\end{tabular}

Based on the normal variance test output using the Chi-square test, the results of the pre- test analysis of calculations, the experimental group showed that count $=9.700, \mathrm{df}=8$, and significant $=0.28$. From the significant level of 0.05 with $\mathrm{df}=8$, it is obtained table $=15.50$ so that the count $<$ table is $9.700<15.50$ and significant $>$ is $0.28>0.05$. So it can be concluded that $\mathrm{H} 0$ is accepted and $\mathrm{H} 1$ is rejected. We can conclude that the data of learning outcomes scores. Then, the test results of normality when using a chi square in Table 7, the calculation of the control class indicates that the count $=3.800$, df $=6$, and a significant 0.70 . From the significant level of 0.05 with $\mathrm{df}=6$, the table $=12.59$ is obtained. So, that the count $<$ table is $3.800<12.59$ significant $>$ that is, $0.70>0.05$. So, $\mathrm{H} 0 \mathrm{~h}$ and $\mathrm{H} 1$ are rejected, and that can be finally concluded. 
An International Multidisciplinary Double-Blind Peer-reviewed Research Journal

The results of the chi-square test analysis value of the calculation analysis obtained from the experimental class showed that count $=2.800, \mathrm{df}=5$, and significant 0.73 . From the chi-square distribution point for significant 0.05 with $\mathrm{df}=5$, table 11.07 is obtained so that the count $<$ table is $2.800<11.07$ and significant $>$ is $0.73>$ 0.05 . Then the value of the analysis results from the control class showed that count $=7,600$, df $=5$, and significant 0.18 . From the percentage point of the chi-square distribution for significant 0.05 with $\mathrm{df}=5$, table 11.07 is obtained so that the count $<$ table is $7.600<11.07$ and significant $<$ is $0.18>0.05$. So $\mathrm{H}_{0}$ is accepted and $\mathrm{H}_{1}$ is rejected.

Table 4. Homogeneity of the two pretest variances of experimental class and control class

Test of Homogeneity of Variances

\begin{tabular}{|l|l|l|l|}
\hline Levene Statistics & df1 & df2 & Sig. \\
\hline 1,136 & 4 & 13 & .383 \\
\hline
\end{tabular}

Based on table 4, the results of the homogeneity of the two pretest variances obtained that the value of Fcount $=$ 1.13 , df $1=4$, df $2=13$. From the percentage point of the $\mathrm{F}$ distribution for probability 0.05 , Ftable $=3.18$ is obtained. It is because Fcount < Ftable, which is $1.13<3.18$, then $\mathrm{H} 0$ is accepted and $\mathrm{H} 1$ is rejected. Then significant homogeneity of the two pretest variances is 0.38 because it is significant $>$ that is $0.38>0.05$. Then $\mathrm{H} 0$ is accepted, and $\mathrm{H} 1$ is rejected

Table 5. Homogeneity of Two Posttest Variances in Experiment Class and Control Class

Test of Homogeneity of Variances

\begin{tabular}{|l|l|l|l|}
\hline Levene Statistics & df1 & df2 & Sig. \\
\hline 1.857 & 4 & 14 & .174 \\
\hline
\end{tabular}

Based on Table 5, the results of the output homogeneity two variants post test were obtained the value of $\mathrm{F}=1.8$ $5, \mathrm{DF} 1=4, \mathrm{DF} 2=14$. From the point percentage to a probability distribution F 0.05 was obtained Ftabel $=3.11$. It is because Fcount $<$ Ftable, which is $1.85<3.11$, then $\mathrm{H} 0$ is accepted, and $\mathrm{H} 1$ is rejected. Then the significant homogeneity of the two posttest variances is 0.17 because it is significant $>0.17>0.05$.

The following is testing the posttest learning outcomes of students in the experimental group Means Independent Simple T-Test. The test uses a significant level of 0.05 or a $95 \%$ confidence level.

Statistical hypothesis:

H0: There is no effect on the use of the World Café Method in improving students' motivation and learning outcomes

H1: There is an effect of using World Café Method in improving students' motivation and learning outcomes.

1). Hypothesis test pre-test experimental class and control class

The results of the Independent Sample T-Test test show that the significant value (sig.2-tailed) with the t-test is 0.403 . Because the significant value is $0.05<0.24$, then $\mathrm{H} 0$ is accepted. Then Tcount $=0.84$ and $\mathrm{df}=38$, from the percentage point distribution table $\mathrm{T}$ with df 38 obtained Ttable $=1.415$, because Tcount $<$ Ttable ie 0.845 $<1.415$ then $\mathrm{H} 0$ is accepted.

2 ). Hypothesis test posttest experimental class and grade control After data processing, display test results independent Sample T-Test postest of experimental and control classes.

The results of the Independent Sample T-Test posttest experimental class and control class show that the value of Tcount $=3.873$, df $=38$ from the $\mathrm{F}$ distribution percentage point table with df 38 obtained Ttable $=0.341$, because Tcount $>$ Ttable that is $3.873>0.341$ then $\mathrm{H} 0$ is rejected and $\mathrm{H} 1$ is accepted. Then the significance is 0.000 , because the significance is $0.000<0.05$, then $\mathrm{H} 0$ is rejected and $\mathrm{H} 1$ is accepted. It can be concluded that the use of the word café method is effective in improving students' learning outcomes of SMP Negeri 1 Mehalaan. So the conclusion from the results of the Independent Sample T-Test posttest for the experimental class and the control class is that the use of the word café method is effective in improving students' mathematics learning achievement.

Table 6. Improved Learning Outcomes of Experiment Class and Control Class

Group Statistics

\begin{tabular}{|ll|l|l|}
\hline & Class & N & mean \\
\hline \multirow{2}{*}{ posttest learning results } & 1 & 20 & 88.50 \\
& 2 & 20 & 59.00 \\
\hline
\end{tabular}


An International Multidisciplinary Double-Blind Peer-reviewed Research Journal

Based on table 6, it can be seen that the increase in the learning scores of the control group students with an average increase of 88.50 and the control class with an average increase of 59.00. So it is known that the average learning value of the experimental group is 29.5 when compared to the control group.

2. The results of the learning value of the experimental and control student activities.

The results of the observation of student activities during the learning process are analyzed and described. The filling in the observation sheet is carried out during the learning process. In this study, learning was carried out in 4 meetings. The results of the observation of students' activities during learning were carried out. In this study, learning was carried out four times

The observations data from the experimental class students in table 9, shows that in the first meeting, the percentage of student activity was $67.05 \%$; in the second meeting, the percentage of student activity was $73.33 \%$; in the third meeting was $80.33 \%$ and in the fourth meeting was $83.33 \%$. Meanwhile, the results of the control class observations in Table 9 show that in the first meeting, the percentage of student activity was $47.05 \%$; in the second meeting, the percentage of students was $73.33 \%$; in the third meeting, the percentage of students was $43.33 \%$, and in the fourth meeting, the percentage of students was 55.83. Based on the overall percentage, it shows that the experimental class students with an average percentage of $76.25 \%$ are in the active criteria, and the control class students with an average percentage of $50.00 \%$ are in the inactive criteria according to the student activity criteria table as follows.

Table 7. Criteria for Student Activity

\begin{tabular}{|l|l|}
\hline Percentage & Active Criteria \\
\hline $90 \leq \% \leq 100$ & Very active \\
\hline $75 \leq \% \leq 90$ & Active \\
\hline $60 \leq \% \leq 75$ & Less Active \\
\hline $40 \leq \% \leq 60$ & Not active \\
\hline $0 \leq \% \leq 40$ & Very Inactive \\
\hline
\end{tabular}

Source: Arikunto (Gerson 2016:33)

\section{The Students' Response of Questionnaire}

The value of the students' response during the learning process carried out, analyzed and described, the charging questionnaire sheet conducted at the end of the lesson is in the last meeting. The obtained values are as below :

Table 8. Data Result of Students' Response on Questionnaire Experiment Class

\begin{tabular}{|l|l|l|l|}
\hline Criteria & \multirow{2}{*}{ Score } & amount & Percentage \\
\cline { 3 - 4 } & & Frequency & $45 \%$ \\
\hline Very Positive & $90-100$ & 9 & $45 \%$ \\
\hline Positive & $75-90$ & 9 & $10 \%$ \\
\hline Less Positive & $60-75$ & 2 & 0 \\
\hline Not Positive & $40-60$ & 0 & 0 \\
\hline Very not positive & $0-40$ & 0 & 100 \\
\hline
\end{tabular}

Based on the value of the Questionnaire response to learners in Table 10 shows the bottom of the 20 statements given there were 9 learners in the criteria of a positive at intervals of $90-100$, ie percent of $45 \%$, also 9 learners who are on positive criteria at intervals of 75-90 the percentage of 45\%, and 2 students who have less positive criteria with an interval of $r$ scores of $60-75$ with a percentage of $10 \%$.

Table 9. Control Class Student Response Questionnaire Results Data

\begin{tabular}{|l|l|l|l|}
\hline Criteria & Score & amount & Percentage \\
\cline { 3 - 4 } & & Frequency & \\
\hline Very Positive & $90-100$ & & $20 \%$ \\
\hline Positive & $75-90$ & 4 & $80 \%$ \\
\hline Less Positive & $60-75$ & 16 & \\
\hline Not Positive & $40-60$ & & \\
\hline Very not positive & $0-40$ & & \\
\hline
\end{tabular}

The data from table 9 shows that from the 20 statements given, there are no students who are in the positive criteria with an interval of $90-100$, and 4 students who are in the positive criteria with an interval of $75-90$ with a percentage of $20 \%$, and 16 students who are in the poor criteria, positive with a score interval of $60-75$ with a percentage of $80 \%$. So, it can be seen that in the use of the passive response method of word cafe students 
An International Multidisciplinary Double-Blind Peer-reviewed Research Journal

based on the overall percentage, it shows that the control group students, namely an average of 85.8 are positive criteria and control class students with an average of 74.6 are in the less positive criteria according to the table.

\section{CONCLUSION}

The conclusion is that the samples from both are normally distributed. Then, the normality test was carried out using the OneWay ANOVA test with a significant level of 0.05 . The results of the One-Way ANOVA test or the F-Test for the experimental class and control class obtained the value Fcount=1,113,df1=4,df2=13,Ftabel=3,18 because Fcount $<$ Ftabel is $1,113<3,18$. So, it is obtained value of Tcount 0.845 with a significant value of 0.000 . Based on the results of the Compeare Mens Independent Samples t-test, it can be concluded that the value tcount $>$ ttabel $(3,873>0,431$ and the significant value is $0,000<0,05$ and it is drawn a conclusion that $\mathrm{H} 0$ rejected and $\mathrm{H} 1$ accepted.

Based on the data in this study suggested course contents, by implementing the World Café method in the classroom related to educational methodologies and the necessity for students to think and experiment like businessmen confirm the results of prior studies Brentnall et al., (2018). The assumption that educational efforts and pedagogical interventions should help students overcome anxiety affects the need to look at affects and emotions. More studies like Keller \& Kozlinska, (2019); guaranteed to show how courses can combine inspiration and motivation to inspire excitement for learning results amongst students. It would assist educators in understanding how their educational interventions and teaching activities can trigger their emotions.

\section{REFERENCES}

Aunurrahman. (2014), Learning and learning. Bandung: Alphabeta VC

Becerikli, S., \& Yıldirım, S. G. (2018). The moral and citizenship education methods performed in the last period of Ottoman. Educational Research and Reviews, 13(16), 609-616.

Brentnall, C., Rodriguez, I. D., Culkin, N. (2018). The contribution of realist evaluation to critical analysis of the effectiveness of entrepreneurship education competitions. Industry and Higher Education, 32(6), 405-417.

Drew, S., Guillemin, M. (2014). From photographs to findings: Visual meaning-making and interpretive engagement in the analysis of participant-generated images. Visual Studies, 29(1), 54-67.

Hanushek, E.A.; Wößmann, L. The Role of Education Quality for Economic Growth; The World Bank: Washington, DC, USA, 2007.

Holsinger, D.B.; Jacob, W.J. Inequality in Education: Comparative and International Perspectives; Springer Science \& Business Media: Berlin, Germany, 2009; Volume 24.

Kadı ־glu, A. Vatanda,slı ־gın dönü,sümü; Metis Yayınları: 'Istanbul, Turkey, 2008.Sustainability 2020, 12, 56 18 of 19

Kozlinska, I, Keller, P. G. (2019). Entrepreneurial affect and emotions in entrepreneurship education impact research: A systematic review and research agenda. Entrepreneurship Education and Pedagogy, 2(4), 281-307.

Ritch, E. L., Brennan, C. (2011). Using World Café and drama to explore older people's experience of financial products and services. International Journal of Consumer Studies, 34(4), 405-411.

Steier, F., Brown, J., Mesquita da Silva, F. (2015). The World Café in action research settings. In Bradbury, H. (Ed.), The Sage handbook of action research (pp. 211-219). Sage.

Sudjana, Nana. 2010. Assessment of Learning Motivation Teaching and Learning Process. : Bandung PT Teenager Rosakarya.

Sugiyono. 2013. The Effect of Educational Research Methods (Quantitative, Qualitative and R\&D Approaches). Bandung : alphabet.

Thomas, V.; Wang, Y.; Fan, X. Measuring Education Inequality: Gini Coefficients of Education; The World Bank: Washington, DC, USA, 1999.

UNESCO. Citizenship Education for the 21st Century, What Is Meant by Citizenship Education? 2019. Available online: http://www.unesco.org/education/tlsf/mods/theme_b/interact/mod07task03/appendix.htm (accessed on 1 November 2019).

Wood, J. 'Preferred futures': Active citizenship, government and young people's voices. Youth Policy. 2010, 105, 50-70. 